Van Deventer, “Aspects of Liminality," OTE 30/2 (2017): 443-458

\title{
Aspects of Liminality in the Book of Daniel
}

\author{
H. J. M. (HANS) VAN DEVENTER (NORTH-WEST UNIVERSITY) ${ }^{1}$
}

\begin{abstract}
Taken at face value, the book of Daniel in the HB seems to occupy a position outside the narrow confines often set in academic (and other) contexts that structure our knowledge, experience and, ultimately, the world we live in. Therefore, OT scholars are debating how this book came to be reckoned among the prophets, while in the HB, it appears in what is traditionally referred to as the writings. Furthermore, the notion of producing a unified text in more than one language (i.e. Hebrew and Aramaic) falls outside the formal, yet unwritten, expectations for literature, both modern and ancient. When one considers the content of the book, inter alia the exilic setting chosen for the book, the position(s) occupied by the main character(s) in the narratives, as well as the symbolic worlds created in the visions, an impression of a text outside, or at least at the border of, expected literary confines is gained. In this article, the concept of liminality will be applied to "explore ... the interpretive power, the hermeneutical reach of the concept" in the book of Daniel (see Gustavo Pérez Firmat, Literature and Liminality, 1986).
\end{abstract}

KEYWORDS: Book of Daniel, liminality, literary criticism, Hebrew Bible

\section{A INTRODUCTION}

Literary criticism of the biblical text has not yet found a proper foothold in the context of South African OT scholarship. Le Roux is well known for the tale he tells about a fork in the road that became apparent in South African biblical scholarship since the early 1970s and, which led this enterprise down a path of either diachronic (historical) or synchronic (text immanent) interpretation. ${ }^{2}$ The scholar being lauded by the present article added his voice to this story by indicating how a shift in scholarly paradigm possibly lies at the heart of this

* Article submitted: 23/04/2017; peer-reviewed: 24/05/2017; accepted: 12/06/2017. H. J. M. (Hans) van Deventer, "Aspects of liminality in the book of Daniel," Old Testament Essays 30 (2017): 443-458, doi: http://dx.doi.org/10.17159/2312$\underline{3621 / 2017 / \mathrm{v} 30 \mathrm{n} 2 \mathrm{a} 15}$

1 The financial assistance from the National Research Foundation through an incentive grant for rated researchers is hereby acknowledged. However, the result presented here remains the view of the author and do not necessarily reflect those of the NRF.

2 Jurie H. le Roux, A Story of Two Ways: Thirty Years of Old Testament Scholarship in South Africa (Pretoria: Verba Vitae, 1993). 
development. ${ }^{3}$ However, much of the subsequent debate between the so-called diachronic and synchronic readings used a restricted notion of synchronic readings that essentially related these to structural criticism (or discourse analysis). To be sure, structural interpretation sits very comfortable under the synchronic umbrella, and arguably, it is the most popular form of synchronic study undertaken in the South African context, but literary criticism entails far more than structural readings.

This contribution seeks to explore another possibility offered by literary criticism when the issue of liminality is investigated in the book of Daniel. Although the term liminality did not originate in a literary context it has found favour with literary critics in their dealings with works of modern and ancient fiction. ${ }^{4}$ In this article, I wish to highlight that this concept may prove helpful in alleviating some of the (historical) problems related to the book of Daniel, as well as provide a possible heuristic tool for understanding the text.

First, I shall consider the origin of liminality as a concept and its application in the field of literary studies. Next, some of the historical problems related to the book of Daniel will be discussed. This is followed by an investigation of how liminality is foregrounded in firstly, the narratives and secondly, the visions in the book of Daniel. Finally, it will be suggested that the concept of liminality opens more possibilities of exploring the OT/HB.

\section{B ESTABLISHING LIMINALITY}

The concept of liminality (from limen [Lat.] "threshold") entered the academic discourse through the work of Van Gennep in the field of anthropology. His book, which was originally published in 1909 and translated into English only in 1960 with the title, The rites of passage, suggests how "ceremonial patterns which accompany a passage from one situation to another or from one cosmic or social world to another" are structured. ${ }^{5}$ Theoretically, these rites include "preliminal rites (rites of separation), liminal rites (rites of transition), and post-

3 Izak J. J. (Sakkie) Spangenberg, "Paradigmaveranderinge in die Bybelwetenskappe: 'n Bydrae tot die gesprek tussen die Bybelwetenskappe en Sistematiese Teologie," R\&Teol 1 (1994): 144-184. Taking up an appointment in the then Department of Biblical Studies at the PU for CHE in the beginning of 1995, this was one of the first articles I read in an attempt to gain some insight in what more seasoned scholars in the field of OT studies busied them with. This article had a huge influence on me carving out an own understanding of the field and it formed a foundation for much of my early research. I am honoured to show my appreciation to Sakkie Spangenberg through this contribution to a Festschrift in his honour.

4 Note for instance some of the contributions to the following collection of essays: Lucy Kay, et al., eds., Mapping Liminalities: Thresholds in Cultural and Literary Texts (Bern: Peter Lang, 2007).

5 Arnold van Gennep, The Rites of Passage, trans. Monika B. Vizedom and Gabrielle I. Caffee (London: Routledge and Kegan Paul, 1960), 10. 
Van Deventer, “Aspects of Liminality,” OTE 30/2 (2017): 443-458

liminal rites (rites of incorporation)." ${ }^{\prime 6}$ The transition, or liminal phase, is temporary, even fleeting in nature and prepares one for a more advanced reunification or incorporation.

Soon after the translation of Van Gennep's work, Victor Turner focused his attention on the liminal phase suggesting that this phase may not be only temporary in nature, but may encompass a more permanent state. ${ }^{7}$ This development accentuated the liminal sphere as, on the one hand a creative context, but on the other hand, as one in which previously fixed boundaries are blurred. In fact, it is a position of eccentricity for the liminal entity (or passenger), where it occupies the periphery in relation to a contextually determined centre. ${ }^{8}$ This means that the liminal phase has both a positive sense of foreshadowing and, in fact, brings forth the new; however, it also involves a negative feel in that it is related to uncertainty, flux, and marginality.

It should be apparent why such a state of "in-between-ness" also appealed to literary theorists, ${ }^{9}$ who are among the users of the term. According to A Dictionary of Literary Terms and Literary Theory, defines the word as: ${ }^{10}$

A term much used in anthropology and literary and cultural theory to designate a space or state which is situated in between other, usually more clearly defined, spaces, periods or identities.

This salient description also clarifies why biblical scholars have turned to the term in their discussions of themes, characters, and literature from the OT. In her aptly titled paper "The Liminal Becoming of the Rebel Vashti," Carruthers investigates the literary afterlife of Queen Vashti who is known only from a few verses in the book of Esther (Esth 1:10-12). Carruthers summarises the aim of her research as "to suggest that the notion of liminality provides a

6 Van Gennep, Rites, 11.

7 Victor Turner, The Ritual Process: Structure and Anti-Structure (Chicago: Aldine Transaction, 1969).

8 Gustavo P. Firmat, Literature and Liminality: Festive Readings in the Hispanic Tradition (Durham: Duke University Press, 1996), xiv.

9 In fact, Mihai I. Spariosu, The Wreath of Wild Olive: Play, Liminality, and the Study of Literature (Albany: State University of New York Press, 1997), 31-32, goes on to suggest that literature itself is liminal in character, in the sense that it is "a threshold or passageway allowing access to alternative worlds that may subsequently become actualized through communal choice and sociocultural practice."

10 John A. Cuddon, A Dictionary of Literary Terms and Literary Theory (Chichester: Wiley-Blackwell, 2013), 398. 
model for understanding the ways in which a character such as Vashti is interpreted in her reception history." 11

A study more directly related to the literature of the OT is Nanette Stahl's ambitious Law and Liminality in the Bible. ${ }^{12}$ She does not spend much time on the theory of liminality before stating: "I will refer to these times of new beginnings and transition, these critical phases in the divine-human relationship as liminal moments" and, "[1]iminal moments are of pivotal importance precisely because of their dynamic, inter-categorical position as transitions leading from one period to another."13 Using this template, she then identifies four liminal episodes, all from the Pentateuch, in which by definition, "law appears as a component."14 Although Stahl's study makes almost exclusive use of forms of literary criticism, the notion of liminality is not used as a heuristic key for gaining new understanding, but rather serves as a fairly general unifying device that connects the sections of the Torah that she discusses. Her theological aim seems to be stressing the universal realisation of the laws in future generations.

A thesis by Krouwer ${ }^{15}$ presents a final and more convincing example of the use of liminality in biblical scholarship, especially OT study. ${ }^{16}$ Firmly rooted in a literary approach to the text, Krouwer uses narrative criticism to identify Moses as God's liminal instrument during the period in the wilderness. This period itself, flanked by a water crossing at its beginning (Sea of Reeds) and end (River Jordan) is characterised as a liminal period due to:

its setting in liminal space (i.e. the wilderness and upon Mount Sinai), the inclusion of liminal events (i.e. divine communication), and the significant transitions the Hebrews underwent, transitions that often necessitate liminal instruments such as water, fire, or a liminal guide. ${ }^{17}$

11 Jo Carruthers, "The Liminal Becoming of the Rebel Vashti," in Mapping Liminalities: Thresholds in Cultural and Literary Texts, ed. Lucy Kay, et al. (Bern: Peter Lang, 2007), 92.

12 Nanette Stahl, Law and Liminality in the Bible (Sheffield: Sheffield Academic Press, 1995). The Bible referred to in the title is more specifically the OT/HB.

13 Stahl, Law, 12.

14 Stahl, Law, 13.

15 David J. Krouwer, "Moses and Liminality," (M.A. diss., University of Denver, 2015), online: $\quad$ http://digitalcommons.du.edu/cgi/viewcontent.cgi?article=1347 \&context=etd.

16 This article focuses on the OT, but the concept of liminality is also used by NT scholars, e.g. B. J. Oropeza, Paul and Apostasy: Eschatology, Perseverance and Falling away in the Corinthian Congregation (Tübingen: Mohr, 2000), 45-48, who refers to this concept in connection with new converts to the Christian community.

17 Krouwer, Moses, 2. 
The significance of Krouwer's work lies not only in his focus on the text itself, and the clear criteria he sets for liminality, but also in the fact that his findings are related to a later period in Jewish history when it is suggested that the liminal character of Moses was also recognised by the community at Khirbet Qumran who "had a close connection with Moses and indeed sought to emulate him."18 Thus, he concludes that:

The Yahad's emulation of the wilderness period supports the narrative analysis of Moses as a liminal character, as it appears that is how the Qumranites understood him as well, evident from their similar use of liminal space, their concern with maintaining purity in their community by means of separation, and their captivation with Moses. ${ }^{19}$

In what follows, I shall draw attention to the way in which liminality is reflected in the form and content of the book of Daniel in the HB. However, this is not merely done because, as far as I know, it has not been done before, but in the hope that some of the results of this inquiry may shed new light on what may be referred to as peculiarities in the book of Daniel. The next section will briefly summarise these peculiarities.

\section{SOME PECULIARITIES IN THE BOOK OF DANIEL}

The critical issues related to the book of Daniel are well-known to OT scholars and include: ${ }^{20}$

- a strange blend of genres with six narratives and four visions dividing the book in two parts of more or less equal length (i.e. narratives in Dan 1-6, and visions in Dan 7-12);

- also, the book is written in two languages: the first story (Dan 1) and the last three visions (Dan 8-12), like most of the HB, are written in Hebrew; while the five stories (or court tales, to be more precise) ${ }^{21}$ in Dan 2-6 and the first of the visions in Dan 7 are written in Aramaic;

- the seemingly different locations of the two parts of the book with the stories probably more related to the 6th century BCE exile of the Judean people, while the visions are perhaps more related to the 2nd century

18 Krouwer, "Moses," 54.

19 Krouwer, "Moses," 79.

20 For a somewhat dated, but still useful summary of these issues, see Philip R. Davies, Daniel, OTG (Sheffield: Sheffield Academic Press, 1985), 11-19.

21 John J. Collins, Daniel, with an Introduction to Apocalyptic Literature, FOTL (Grand Rapids: Eerdmans, 1984), 42, defines this subgenre as "the story of adventures at a royal court." 
BCE purge of a large part of the Jewish population in Jerusalem by Antiochus IV Epiphanes; and

- lastly, it should be noted that there are a number of differences between two ancient Greek versions of the book, namely that of Theodotion, and what is referred to as the Old Greek version.

Usually, these issues related to language, genre, social setting, and textual criticism are part and parcel of the academic discourse on every book of the HB. However, it stands to reason that in the book of Daniel these issues are quite glaring, even from a superficial reading. One of the consequences of these features in the book of Daniel is that in modern (and even ancient) ${ }^{22}$ times uncertainty remains with regard to where this book should fit into the categories that have been created to assist the human quest of making sense of the world. Therefore, discussions about when, where, and why the book of Daniel was included as part of an authoritative textual tradition are on-going.

Theories in this regard all find a place on a continuum of which the opposing ends relate to later categories of canonicity. Those referring to a tripartite canon (consisting of Law, Prophets and Writings) explain that the book of Daniel lost its place among the prophets and was relegated to the writings due to what, in harsh terminology, can be labelled as its failed prophecy. ${ }^{23}$ However, the supporters of this view do not make clear the reason for why the book in toto was not discarded from such "canonical" lists. Another explanation from the same side of the continuum states, somewhat anachronistically, that the prophetic division of the canon was already "closed" by the time the book of Daniel was completed. Thus the book found a place only among the "writings." 24 An opposing view, which breaks with the idea of a tri-partite division for the Hebrew Scriptures, sees the book of Daniel as keeping its place among the prophets if the tripartite limitations are lifted in favour of a bipartite division of the sacred text into Law and Prophets. ${ }^{25}$ In this article, I shall treat these peculiarities in the book of Daniel that produced so much scholarly discussion as possibly part of the creative process that originally produced the book. ${ }^{26}$

22 Klaus Koch, “Is Daniel among the Prophets?” Int 39 (1985): 117-130, even suggests that the Rabbi's removed the book from its position among the prophetic books and placed it with the Writings.

23 E.g. Koch, "Is Daniel?".

24 E.g. Raymond Hammer, The Book of Daniel (Cambridge: Cambridge University Press, 1976), 1.

25 John Barton, Oracles of God: Perceptions of Ancient Prophecy in Israel after the Exile (Oxford: Oxford University Press, 2007), 44, cf. 36-37.

26 I hope to indicate that this is not another case of a literary approach seeking to downplay, or plainly ignore historical questions. This will be achieved by constant 
Van Deventer, “Aspects of Liminality,” OTE 30/2 (2017): 443-458

The rest of the article will focus on liminality in the book of Daniel and I wish to convincingly argue that: 1) we find clear indications of a liminal context created by time, space and characters in the book of Daniel; 2) that this liminal context is intended as an extended period, rather than a fleeting moment; and 3) that in the process, the text inverts the world in order to introduce a major new line of thought previously reflected only in marginal positions.

\section{LIMINALITY IN THE NARRATIVES}

Liminality can be expressed in more ways than one. In what is seen as a classical definition of liminality, Victor Turner explains that:

Liminal entities are neither here nor there; they are betwixt and between the positions assigned and arrayed by law, custom, convention, and ceremonial. As such, their ambiguous and indeterminate attributes are expressed by a rich variety of symbols in the many societies that ritualize social and cultural transitions. ${ }^{27}$

From this perspective, the period of exile, which not only brackets the introductory chapter as well as the narratives as such, but in fact also the book as a whole, ${ }^{28}$ can be viewed as indicative of liminality. The Jewish characters are removed from what to them are familiar spaces with regard to their land, city, and religion and they are brought to an unfamiliar setting. The fact that the book was probably written and edited ${ }^{29}$ in the second century BCE and that the author(s) decided to use the exile as backdrop, should not go unnoticed. The author(s) probably saw in this liminal period a reflection of their own time during which they experienced in their own land, city, and religion a period of

reference to the time of crisis in the second century $\mathrm{BCE}$ that produced the book of Daniel in the HB.

27 Turner, Ritual Process, 95.

28 Note the signal to the beginning (1:1-2) and end (1:21) of the period of the exile by means of reference to Nebuchadnezzar and Cyrus in the first chapter, as well at the end of the narrative section (the reference to Cyrus in 6:29) and with the beginning of the last vision (Cyrus in 10:1).

29 The use of earlier material available to the editors or authors is not excluded. For the general accepted redaction history of the book, see John J. Collins, Daniel, Hermen (Minneapolis: Fortress, 1993), 38; for a recent proposal prioritising the prophetic origins of the book, see H. J. M. (Hans) van Deventer, "Another Look at the Redaction History of the Book of Daniel, or, Reading Daniel from Left to Right," JSOT 38 (2013): 39-60. 
unfamiliarity whilst suffering unprecedented persecution under Antiochus Epiphanes. ${ }^{30}$

The use of the period of "exile" as indicator of liminality also locates this concept in the sense proposed by Turner, namely that it need not only be a fleeting moment between "here" and "there," but a longer experience of "statuslessness." "I1 In the book of Daniel, this uncertainty regarding the period of distress explicitly comes to the fore in Dan 9 (reinterpretation of the seventy years prophesied by Jeremiah; v. 24) and Dan 12 (reinterpretation of the text's own set of numbers; v. 12).

Turning our attention to the six narratives in the first part of the book, the first chapter of the book testifies to spatial liminality, with the protagonists forming part of a group of young men captured by Nebuchadnezzar during a siege of Jerusalem (Dan 1:6). The chapter is bracketed by the names of the "superpower" leaders who were, on the one hand, responsible for the exile (Nebuchadnezzar of Babylon) and, on the other hand, for its end (Cyrus of Persia). Per definition, exile represents a liminal state: ${ }^{32}$ people are taken away from their known place(s) of belonging and placed in a foreign context. The first narrative in the book of Daniel captures this liminality well with its reference to how the young captives ${ }^{33}$ are introduced to training to equip them for service at the foreign court, through learning a new language, following a new lifestyle with a change in diet, and receiving new names (Dan 1:4-7). Such a liminal state is rather unsettling and at the same time offered opportunity for creativeness, as Krouwer explains: ${ }^{34}$

because these states are not bound, they are creative and thus powerful, able to receive input from sources outside of either state on either side of the transition, and thus are powerful states by virtue of their creative potential.

30 Anathea E. Portier-Young, Apocalypse against Empire: Theologies of Resistance in Early Judaism (Grand Rapids: Eerdmans, 2011), 176-178, lists possible reasons for Antiochus" "baffling" conduct.

31 Turner, Ritual Process, 97.

32 Victor Turner, "Process, System, and Symbol: A New Anthropological Synthesis," Daed 106 (1977): 61-80, lists "exile" and "prison" among "liminal situations," 75.

33 Turner, Ritual Process, 95, notes that neophytes typically are "liminal entities." As such the four Jewish characters introduced by name in Dan 1 epitomises the notion of liminality.

34 Krouwer, "Moses," 12. Reference to such creativeness in the exile as a liminal space is provided by many introductory textbooks on the HB stating that during the 6th century exile much of the writing and editing of earlier material took place, see e.g. John J. Collins, A Short Introduction to the Hebrew Bible, 2nd ed. (Minneapolis: Fortress, 2014), 122 on the redaction of the Deuteronomistic History. 
At the onset of the book, the context of exile creates the literary possibility for something new to come into existence. However, what this new idea is or what the new possibilities are, is not immediately evident from the first story. It seems as if only the broader context of the exile is introduced, along with the training of the Judean nobles at the court of their captor. As captives, they are mere objects of the actions of others. ${ }^{35}$ In fact, they are liminal characters undergoing training that will result in their ultimate immersion into the Babylonian way of life. These characters are stripped of their customs and cultural values, and as the first step into a new world, they are given new names (Dan 1:7).

As the story develops, the focus is narrowed eventually to only four of these young Jewish men. Intriguingly, these four wish to set themselves further apart from the rest of the liminal characters. In the story world they set themselves betwixt the captive Judean nobles and the in-control Babylonian overseers in what one may describe as a position of double or intensified liminality. ${ }^{36}$ However, when their resolution not to defile themselves with the rich food from the king's table, which bears the intended fruit, they become the first among equals as their better appearances indeed set them apart from the rest of the captives. Their initial separation leads to their eventual exaltation.

One of them, Daniel, the main character in the book, acquires a supreme liminal position - that of dream interpreter (Dan 1:17). Such a person stands between the visible mundane world and an unseen alternative reality. Daniel is able to occupy this liminal space due to his ability to translate symbols from the other world into meaningful language in the real world, albeit a narrative world in this instance.

Thus, the opening chapter in the book of Daniel constructs liminal spaces and characters - by doing so, the reader is alerted to the possible presence of such literary constructs in the rest of the book. In fact, it is this first chapter that reflects these liminal aspects the clearest; consequently creating a context in which to read the rest of the book.

In ch. 2, the extraordinary claim in the opening chapter regarding Daniel's ability to gain insight into dreams and visions, and thus being a true liminal character, is proven by means of a story. Once again the focus is narrowed from the initial characters claiming to occupy the liminal space between the dream world and reality, namely the king's magicians, the enchanters, the sorcerers, and the Chaldeans (Dan 2:2), to the person of Daniel

35 David M. Valeta, Lions and Ovens and Visions: A Satirical Reading of Daniel 1-6 (Sheffield: Phoenix, 2008), 68.

36 The term is borrowed from Sang Hyun Lee, From a Liminal Place: An AsianAmerican Theology (Minneapolis: Fortress, 2010), 36, which he uses to describe the place of Asian Americans. 
(Dan 2:25). In this case, Daniel, unlike his Babylonian counterparts, is able not only to interpret the dream of the king, but far more superior, he is also able to tell the king what he dreamt - a dream about a huge statue made from different materials. Daniel's liminal position is emphasised when the king's executive officer announces that he found this person among the Judean exiles (Dan 2:25). In his response to the king, Daniel reaffirms this liminal position by making it quite clear that he is acting as a go-between "the God in heaven" and the king (Dan 2:28). In this, and similar contexts in the book, the dreamer is not viewed as a truly liminal character, although he does find himself in a liminal state. This is the result of the transfer of agency from the dreamer to another character "who is treated with fear, deference, or devotion." 37 In the story world, as in the real world, this creates tension and fear in the dreamer. In the book of Daniel, the services of an authentic liminal character are called for to alleviate this imbalance between the dreamer and the character(s) seen in the dream.

The narratives in Dan 3 and 6 are both stories of persecution and are closely connected. ${ }^{38}$ It makes sense to group these chapters together in the discussion. In the first story, the three friends of Daniel, who were introduced in ch. 1, refuse to obey the command of the king (Nebuchadnezzar in the story world) to worship a gigantic statue erected by him. In the second story, Daniel refuses to worship the king himself (Darius in the story world). For their trouble, or in fact lack thereof, the three men in Dan 3 face a certain fiery death since the lack of compliance to the king's edict carried the punishment of being thrown into a "furnace of blazing fire" (NRSV - Dan 3:6). Daniel, in ch. 6, is thrown into a lion's pit where a sure death awaits him (Dan 6:7). In these narratives, liminality is presented in spatial terms. Turner notes, "liminality is frequently likened to death"; 39 thus, the furnace and pit become those uninhabitable spaces on the border of existence where life in the story world is surely to be lost. In these stories, however, the forces of nature are subverted, and instead of demise, these very real death traps bring forth life when the protagonists are miraculously rescued to the amazement of the kings involved (Dan 3:28; 6:24-25).

In Dan 4 and 5 the theme of Daniel's interpretive gift is reintroduced. However, unlike in ch. 2, he is given more to work with here - the king tells him the dream about a huge tree (ch. 4) and a strange message is written on a wall (ch. 5). It was noted above that a dream interpreter is seen as a liminal

37 Patrick McNamara, Dreams and Visions: How Religious Ideas Emerge in Sleep and Dreams (Westport: Praeger, 2016), 102.

38 John Goldingay, Daniel, WBC (Dallas: Word Books, 1989), 327, refers to the chiastic structure of Dan 2-7 with chs. 2 and 7, 3 and 6, as well as 4 and 5, closely related.

39 Turner, Ritual Process, 95. 
character due to the ability of relating messages from another world to the present world. In the case of Dan 4, it is not only Daniel that represents liminality, though. Basson indicated how the king (Nebuchadnezzar in the story world) "has an ambivalent status because he straddles the boundary between civilisation and nature" and furthermore "epitomises liminality for he is the civilised man turned animal." ${ }^{40}$ The passage Basson deals with of the king going from the human world to the animal world and back fits nicely into Van Gennep's original explanation of rites of passage. In this case, liminality presents a temporary phase between separation and re-aggregation. Although the present article is more concerned with the notion of liminality as a permanent state, as developed by Turner and often used in literary discussions, other expressions of liminality should also be noted. In the sense developed by Turner, Daniel as interpreter operating in the space between the real and other worlds seems to occupy a much more permanent place as a liminal character. In ch. 5, such liminality is reiterated with the addition that Daniel comes from among the Judean exiles, who are themselves in a state of limbo.

The notion of liminality noted in the first narrative (Dan 1) is taken up in the rest of the narrative section of the book of Daniel. Especially the social category of being an exile linked to the ability of acting as a go-between in a real and a dream world, as well as surviving situations of death highlights the liminal aspects in this section of the book.

\section{E LIMINALITY IN THE VISIONS}

In Dan 7, a whole new world awaits the main character (Daniel) and the reader when the genre of the book changes abruptly. Daniel, who in the narrative section interpreted dreams, now has to deal with dreams of his own. Like the foreign kings in the narrative section of the book, Daniel receives a revelation through a dream. The reader is drawn into the text by means of Daniel's first person description of what he sees (from v. 2), and that stands in contrast to the third person narrative style in the previous chapters. Through the eyes of the visionary, the reader witnesses bizarre images. Both are all the more perplexed: firstly, by the strangeness of the creatures described in the visions, and secondly, by the visionary's lack of understanding what these images may mean. The world of the narrative section of the book is turned upside down. ${ }^{41}$ Here, an angel, ${ }^{42}$ per definition a liminal being, has to enter the narrative world to act as dream interpreter. Whereas in the narrative part of the book, Daniel

40 Alec Basson, "'A King in the Grass': Liminality and Inversion in Daniel 4:28-37," JSem 18 (2009): 1-14.

41 Dean A. Nicholas, The Trickster Revisited: Deception as a Motif in the Pentateuch (Bern: Peter Lang, 2009), 97, reminds us that "the liminal region contained both chaos and danger and divine revelation and call" (emphasis original).

42 Collins, Daniel (Hermen.), 335, is confident that holy one "here means angel." 
stood in the real world and had access to another world to gain insight into dreams and visions, here we find someone from another world entering the real world to aid understanding.

The vision itself transports both visionary and reader to a foreign and symbolic universe. In this world, foreign rulers are depicted as outlandish animals, and it even allows a glimpse of God depicted as an "ancient of days" seated on a throne (Dan 7:9). Despite an interpretation given for understanding who these surreal beings are, and what they are doing, the visionary, and reader, are still left puzzled and even scared. Excluding a few minor details, Daniel experiences the same physical reaction to the vision and its interpretation than what King Nebuchadnezzar suffered when he had the dream of the huge tree before its meaning was made known to him. ${ }^{43}$ Although written in the third person, we are told that King Belshazzar experienced the same reaction when he saw the handwriting on the wall (compare Dan 5:6 and $7: 15,28)$. This indicates that Daniel did not fully comprehend the vision he saw or the interpretation that he received. The reader also fails to grasp what is happening. Just like the visionary, the reader is left in limbo.

The next vision, in Dan 8, does not help to improve this experience in any great measure, although the now the foreign kings are depicted as domesticated animals, namely a ram and a goat. But, the structure of the vision remains the same: a liminal character from another world is introduced (Dan 8:15-16) to explain the vision seen by Daniel. Daniel's physical response remains indicative of his inability to comprehend the matter at hand; he loses consciousness after the vision (Dan 8:18) and is left "ill for many days" after its interpretation (Dan 8:27). Daniel 9 relates to the previous two visions only in the sense that an interpreter from outside the mundane realm needs to intervene to explain to Daniel what he read in the book of the prophet Jeremiah. In this instance, neither the reading nor its interpretation has any physical effect on him.

In Dan 10-12, the last vision in the books is communicated. Here, the earthly kings have evolved from their previous animal forms. Furthermore, the physical impact of this vision on Daniel is described in much more detail, and almost the whole of ch. 10 deals with his physical weakness and how he needs to be supported by otherworldly beings. The first person account of this vision (10:2-3) stands in stark contrast with the narrator's opening remarks that Daniel understood the word and had insight into the vision (10:1). As in the rest of the visionary part of the book, the idea of liminality is restricted almost solely to

43 Compare Dan 4:2 (MT) with Dan 7:15, 28 and note the use of יבַהְלְנִּנִ (I was alarmed) in each instance. It is noteworthy that even the interpretation by the angel does not alleviate this condition in the case of Daniel. 
the character of the vision interpreter, who in this case, is an angelic being acting as a messenger between the heavenly and earthly realms. ${ }^{44}$

However, one new major idea is introduced towards the end of this last vision in the book; an idea that to this day influences religious thought in contexts where this text is read as part of the OT. In Dan 12:3 it states: "And many who sleep in the dust of the earth will awaken-these for eternal life, and those for disgrace, for eternal abhorrence." Collins clarifies the importance of these words when he notes: "Daniel 12:2-3 is the only clear attestation of belief in resurrection in the Hebrew Bible." 45 These verses represent not only a leap in theological development in the OT, but also underscore the potency of liminal places for the development of new (religious) ideas. In this context, it is important to note the following observation by Krouwer: ${ }^{46}$

Death can be understood as the final liminal experience of life. It is the event that marks the transition from this life to what lies ahead, whether it be heaven, hell, nothingness, reincarnation, or Sheol: the dark, dank afterlife model of the Hebrew Bible ... Whatever one believes about the afterlife, death is still the final transition of one's existence.

Although he recognises that this notion about a resurrection links to earlier hints in this regard in the HB, he emphasises the radical newness of this idea as follows: 47

No biblical text before Daniel had spoken, even metaphorically, of a double resurrection of the righteous and the wicked and a judgment of the dead.

This development of an idea that Collins refers to as a "minority view," found fertile ground in the context of liminality created by content of the book of Daniel as described above. These liminal aspects in the book of Daniel, to my mind, played a major part in inspiring the "considerable innovation" involved $^{48}$ in creating these new ideas about resurrection. Finally, a few remarks will be made on how the structure of this book, linked to the historical problems noted above, may be reinterpreted in light of these liminal aspects.

44 Krouwer, "Moses," 14, reminds us that "[b]irth, death, and otherworldly interaction all involve bridging the gap between realms, and so are intrinsically liminal in nature. Otherworldly interaction can involve visions of the otherworldly, communication with beings from another realm ..."

45 Collins, Daniel (Hermen.), 394.

46 Krouwer, "Moses," 48.

47 Collins, Daniel (Hermen.), 395.

48 Collins, Daniel (Hermen.), 395. 


\section{F LIMINALITY AS HEURISTIC TOOL}

This article sought to indicate how the content of the book of Daniel creates the possibility to link this book to the notion of liminality. This mainly comes to the fore in inter alia the exilic context chosen for the book, the character of different dream interpreters the reader encounters, as well as the ultimate reinterpretation of death not as an end to life, but as an in-between state. Death becomes a link between this world and a next in which the dead will awaken. This is the ultimate end towards which the book of Daniel is working. Even in the perilous present, while suffering in the aftermath of the persecution under Antiochus Epiphanes, the book's audience may find comfort in the hope of another life on the other side of the limen.

Of course, the concept of liminality is a recent one and did not originate or exist in the ancient world. However, this article shows how the idea of liminality, as employed in literary studies, like other literary terms produced by modern literary theory, may be used to aid a modern understanding of biblical texts. Referring back to the critical issues noted above regarding the book of Daniel, it seems that at least three of the four issues listed above may be connected to the manifestation of liminality in literary products. The book in its final form, escapes a neat classification with regard to genre, language, and social location..$^{49}$ It is neither here, nor there. Thus, the liminal aspect of the book extends beyond its content to its form, reminding of the old adage that when it comes to literary criticism, "form and content are inseparable." 50

One of the major contributions of the book of Daniel to OT and biblical theology is the introduction of resurrection as a final outcome after the death of a person. This theological leap went against nearly everything the OT teaches about the nature of death. The unprecedented period of insecurity presented by the persecution of Antiochus Epiphanes created the atmosphere to produce a radically new idea about death. Since a liminal world provides the perfect place for the development of creative new ideas, it seems that the authors of the book of Daniel, in their selection and writing of the material, inadvertently tapped into the possibilities provided by the literary notion of liminality. The fact that this, and other literary features in biblical texts, are only being uncovered fairly recently, does not take away from the contribution these features can make to our understanding of the biblical text.

49 One reviewer pointed out that the placement of the book of Daniel in different canonical traditions, i.e. as part of the Khetubim in the Tenach and as part of the prophets in the OT, might also allude to its liminal character. I wish to thank him/her for sharing this thought that I did not explore here.

50 Phyllis Trible, God and the Rhetoric of Sexuality (Minneapolis: Fortress, 1978), 9, citing René Wellek in this regard. 
Van Deventer, “Aspects of Liminality,” OTE 30/2 (2017): 443-458

\section{BIBLIOGRAPHY}

Barton, John. Oracles of God: Perceptions of Ancient Prophecy in Israel after the Exile. Oxford: Oxford University Press, 2007.

Basson, Alec. "“A King in the Grass': Liminality and Inversion in Daniel 4:28-37." JSem 18/1 (2009):1-14.

Carruthers, Jo. "The Liminal Becoming of the Rebel Vashti." Pages 91-110 in Mapping Liminalities: Thresholds in Cultural and Literary Texts. Edited by Lucy Kay, Zoë Kinsley, Terry Phillips and Alan Roughley. Bern: Peter Lang, 2007.

Collins, John J. Daniel, with an Introduction to Apocalyptic Literature. FOTL. Grand Rapids: Eerdmans, 1984.

. Daniel. Hermen. Minneapolis: Fortress, 1993.

. A Short Introduction to the Hebrew Bible. 2nd ed. Minneapolis: Fortress, 2014.

Cuddon, John A. A Dictionary of Literary Terms and Literary Theory. Chichester: Wiley-Blackwell, 2013.

Davies, Philip R. Daniel. OTG. Sheffield: Sheffield Academic Press, 1985.

Firmat, Gustavo P. Literature and Liminality: Festive Readings in the Hispanic Tradition. Durham: Duke University Press, 1996.

Goldingay, John. Daniel. WBC. Dallas: Word Books, 1989.

Hammer, Raymond. The Book of Daniel. Cambridge: Cambridge University Press, 1976.

Kay, Lucy, Zoë Kinsley, Terry Phillips, and Alan Roughley, eds. Mapping Liminalities: Thresholds in Cultural and Literary Texts. Bern: Peter Lang, 2007.

Koch, Klaus. "Is Daniel among the Prophets?" Int 39/2 (1985): 117-130.

Krouwer, David J. "Moses and Liminality.” M.A. diss., University of Denver, 2015. Online: $\underline{\text { http://digitalcommons.du.edu/cgi/viewcontent.cgi?article }=1347}$ \&context=etd.

Lee, Sang Hyun. From a Liminal Place: An Asian-American Theology. Minneapolis: Fortress, 2010.

Le Roux, Jurie H. A Story of Two Ways: Thirty Years of Old Testament Scholarship in South Africa. Pretoria: Verba Vitae, 1993.

McNamara, Patrick. Dreams and Visions: How Religious Ideas Emerge in Sleep and Dreams. Westport: Praeger, 2016.

Nicholas, Dean A. The Trickster Revisited: Deception as a Motif in the Pentateuch. Bern: Peter Lang, 2009.

Oropeza, B. J. Paul and Apostasy: Eschatology, Perseverance and Falling Away in the Corinthian Congregation. Tübingen: Mohr, 2000.

Portier-Young, Anathea E. Apocalypse against Empire: Theologies of Resistance in Early Judaism. Grand Rapids: Eerdmans, 2011.

Spangenberg, Izak J. J. (Sakkie). "Paradigmaveranderinge in die Bybelwetenskappe: 'n Bydrae tot die Gesprek tussen die Bybelwetenskappe en Sistematiese Teologie.” R\&Teol 1/2 (1994): 144-184.

Spariosu, Mihai I. The Wreath of Wild Olive: Play, Liminality, and the Study of Literature. Albany: State University of New York Press, 1997.

Stahl, Nanette. Law and Liminality in the Bible. Sheffield: Sheffield Academic Press, 1995. 
458 Van Deventer, “Aspects of Liminality,” OTE 30/2 (2017): 443-458

Trible, Phyllis. God and the Rhetoric of Sexuality. Minneapolis: Fortress, 1978.

Turner, Victor. The Ritual Process: Structure and Anti-Structure. Chicago: Aldine Transaction, 1969. . "Process, System, and Symbol: A New Anthropological Synthesis." Daedalus 106/3 (1977): 61-80.

Valeta, David M. Lions and Ovens and Visions: A Satirical Reading of Daniel 1-6. Sheffield: Phoenix, 2008.

Van Deventer H. J. M. (Hans). "Another Look at the Redaction History of the Book of Daniel, or, Reading Daniel from Left to Right.” JSOT 38/2 (2013): 39-60.

Van Gennep, Arnold. The Rites of Passage. Translated by Monika B. Vizedom and Gabrielle I. Caffee. London: Routledge and Kegan Paul, 1960.

Van Deventer, H. J. M. (Hans). Research Focus Area Ancient Texts: Text, Context, and Reception, North-West University, PO Box 1174, Vanderbijlpark, 1900, RSA. Email: hans.vandeventer@nwu.ac.za. 